\title{
La censura del cuento de Blancanieves durante las dictaduras de Franco y Salazar ${ }^{1}$
}

\author{
Ramón Tena Eernández \\ Universidad de Extremadura
}

Angela Balça

Universidad de Évora | CIEC

José soto Vázquez.

Universidad de Extremadura

Martin Gómez Ullate-García de León

Universidad de Extremadura

\section{Los cuentos de hadas}

Los cuentos de hadas han sido investigados desde múltiples perspectivas e hipótesis que han enriquecido el estudio de la literatura infantil y juvenil a lo largo del tiempo (Ruiz de Elvira, A. 1975; Cixous, H. y Clément, C. 1975; Bettelheim, B. 1976; Ruiz Campos, A. M. 2000; Perera Santana, Á. 2007). Entre estos trabajos ha suscitado gran interés el análisis de las historias pertenecientes a la tradición oral (Mourey, L. 1978) y registradas por autores como Charles Perrault mediante los Contes du temps passé avec moralités (1697) o Kinder und Hausmärchen (1812) de los hermanos Grimm (Silva, M. E. 2014 y Martens, H. 2016). En ambos casos son comunes el cuento de Caperucita Roja, La Bella durmiente o La cenicienta. Sin embargo, Blancanieves no se incluyó en el recopilatorio de Perrault, este hecho abre todo tipo de elucubraciones, ya que a partir de esa diferencia han convivido dos teorías: una, el posible desconocimiento del adaptador acerca de este cuento, pues la recopilación de los hermanos Grimm tuvo lugar un siglo después de su obra, la segunda es que considerase que el relato era demasiado cruel.

Esta última teoría cobra fuerza en la literatura científica, pues aclaran que, aunque no fueran relatos ideados expresamente para nińos, incluso los adultos se quejaban del exceso de escenas terroríficas. Sin embargo, aunque habría que hacer un estudio detallado de cada 
cuento, se atribuye mayor dramatismo a los relatos alemanes, especialmente cuando la protagonista era una mujer. Así lo contempla de manera generalizada el trabajo de Segura (229), que determina que una de las características de los cuentos de los hermanos Grimm es una violencia gratuita en relación a las mujeres y una fuerte misoginia. En el caso de Perrault, aunque también hay espacio para los desenlaces tremebundos, confluyen dos motivos que rebajan la crudeza. Uno de ellos es la inclusión de aspectos jocosos en medio del relato y el segundo es el contexto histórico en el que se escriben. Muchas de sus historias se narraban públicamente en ambientes aristocráticos de la sociedad francesa (Muir, P. 1954/1985), y en ese contexto (Zapata, T. 2007), no solo era importante la carga moral, también el deleite del receptor con un final moralizante y justo (Simonsen, M. 1992).

Entre las investigaciones contemporáneas que profundizan en este tipo de cuestiones y dedican una atención preferente al cuento de Blancanieves podemos citar a Begué (2016), que analiza su modelo de feminidad; a Sánchez (2014) que desvela sus adaptaciones históricas; y a Guichot y Bono (2001), que evalúan los roles sociales de los personajes. A este grupo podemos añadir los estudios de Martí (2013), que valora minuciosamente el papel de las princesas en los géneros infantiles, o a Nieves Martín (2016), que desbroza la evolución de los cuentos de hadas recopilados tanto por Charles Perrault como por los hermanos Grimm.

\section{Características históricas del cuento de Blancanieves}

Nuestro relato, procedente de la cultura popular y divulgada por los hermanos Grimm, tiene su reconocimiento en la actualidad entre la población infantil debido en gran parte a la factoría Disney. Así al menos lo asevera la investigadora Segura (2014), que expone como su éxito se impulsó en 1937 con la creación de la película Snow White and the Seven Dwarfs, que resultó muy atractivo para la infancia por incluir dibujos animados a color. No obstante, a su aceptación contribuyó el arraigo previo en la memoria colectiva de cualquier familia europea. Aquí debemos tener en cuenta que la sociedad del siglo XIX y principios del XX era mayoritariamente patriarcal y quienes solían narrar estas historias a las niñas eran las mujeres. No porque el cuento hubiese sido ideado con esta finalidad, sino porque para los varones se preferían los relatos de carácter policiaco o de aventuras. Por tanto, estamos ante un argumento transmitido por y para mujeres, donde los valores implícitos que recibían las niñas se asentaba con mayor facilidad.

Ahí reside la debilidad de esta narración, en la tentación de manipular su esencia en función del interés de quien lo narrara o supervisase la edición. Como clásico, se confiaba en que cada familia lo seguiría revelando a las nuevas generaciones, la cuestión que pretendemos analizar es cómo y de qué manera se produjo. Es conocido que incluso en fechas previas a las censuras de algunas dictaduras, el relato tuvo que ser adaptado para reducir la crueldad de algunos pasajes. Prueba de ello es que en 1937 Disney reduce los tres intentos de matar a Blancanieves a uno y suaviza el cruento desenlace de la madrastra. En el relato original (McGlathery, J. 1991) se expresa que moría bailando sobre unas sandalias de hierro ardiendo y en la película encontramos la caída por una ladera rocosa (Martínez, M. M. 2014; Begué, P. 2016).

Estos no son los únicos cambios que ha sufrido el cuento. La investigadora Nieves Martín (2016) explica que para adaptarse a los valores morales de cada época y país, su 
autocensura ha sido continuada. En el caso español ha calado la idea de que el personaje malévolo fue una madrastra, pero se obvia por completo que en la versión original era su madre carnal (Basile 207-210). La modificación protegía el concepto de maternidad defendido por el catolicismo, que entendía esta figura como un ser cándido por naturaleza, sin capacidad para obrar el mal, por muy grandes que fueran las adversidades. En este sentido, el estudio de Segura (222) aprecia que, aunque las lecturas para la infancia puedan parecer ingenuas o meros entretenimientos para nińos, realmente han servido como instrumentos para modelar su pensamiento y comportamiento. Razón por la cual, Martín (2016) nos invita en las conclusiones de su investigación a interesarnos por la trayectoria de Blancanieves durante las dictaduras.

La recepción de los hermanos Grimm en España ha sido muy diversa. Durante el siglo XIX tenemos, como ejemplo, la traducción de José S. Viedma (1866) o las posteriores ediciones de final de siglo de Emma Von Bánaston (1885), así como las francesas de los hermanos Garnier (1886). En el primer tercio del siglo XX siguieron siendo numerosas las ediciones, como muestra la traducción de Pedro Pedraza y Páez (1933). En plena dictadura hayamos la traducción de Blancanieves y los enanitos por Mercedes Llimona (1941), la adaptación teatral de José María Fernández (1950) o Francisco Payarols (1955), y un largo etcétera que sería extenso de enumerar. Del mismo modo, en Portugal, la recepción de los hermanos Grimm fue muy diversa. Alrededor de 1830 aparecieron las primeras traducciones en lengua portuguesa, en prensa y revistas principalmente. A comienzos del siglo XX surgen las traducciones de Henrique Marques Júnior, para la Biblioteca das Crianças (1898-1910); también de estas fechas son las traducciones de Carolina Michaëlis de Vasconcelos. Hasta 1974, fueron surgiendo muchas publicaciones y adaptaciones de los cuentos de los hermanos Grimm, como Para as Crianças: Alguns Contos de Grimm (1908), de Ana de Castro Osório; Contos de Grimm (1923), de la editora Figueirinhas y O gato das botas, de Ricardo Alberty (1970), entre otros.

Centrándonos en este último periodo, resulta clave el estudio de la literatura infantil y juvenil española de García Padrino (42 y ss.), pues además de existir una censura estatal, de consulta previa y de carácter oficial, la iglesia estuvo implicada, tanto en calidad de agente evaluador (sacerdotes censores), como de revisión. Es decir, entre los ítems con los que se juzgaba la idoneidad de cada cuento estaba la mención explícita a una vigilancia expresa de que no existiera materia punible que dańara la imagen de la iglesia, el dogma católico o los representantes de la institución. Asimismo, esas cuestiones no conformaban un único punto de evaluación, los tres factores se examinaron de manera independiente y prueba de su relevancia es que se publicaron en el Boletín Oficial del Estado (MIT, 1955) pautas de redacción sobre las alusiones al demonio que se hacían en algunos cuentos fantásticos infantiles.

Así, nuestro deseo es continuar con las investigaciones ya citadas, pues si Blancanieves se había ido dulcificando de manera voluntaria y acorde con los valores cristianos, ¿qué sucedería cuándo esa antigua voluntariedad se tornara en imposición gubernamental? En el Reglamento de Publicaciones de literatura infantil y juvenil (1955) se indicaba abiertamente que, para proteger la educación infantil no tendrían cabida las escenas terroríficas que pudieran afectar psicológicamente a los niños, ni la venganza o la violencia de algunos relatos para proteger su moral. Esta normativa ya vaticina cómo podría ser la 
evaluación del franquismo del relato de Blancanieves cuando su argumento se mantenía muy apegado a la versión original escrita por los hermanos Grimm en 1812.

Los recopiladores alemanes son descritos en la investigación de Segura (229) como complicados, negativos, terroríficos y tortuosos, que hacen de la crueldad de sus relatos una seña de identidad. Esta definición es la antítesis perfecta del prototipo de cuentos que quería promover la dictadura española, sobre todo cuando el lector modelo eran niñas. De este modo registra en su reglamento, que expone abiertamente que la censura prohibirá las narraciones que evidencien una concepción de la vida como sucesión de constantes peligros, casi siempre siniestros o sin lugar para el optimismo y la esperanza (MIT 843). Si valoramos que en el volumen inicial de 1812 se describieron hasta tres intentos de asesinato a una Blancanieves de tan solo siete ańos de edad, podríamos afirmar que la protagonista no vivía en el remanso de paz que la censura intentaba potenciar como contexto común de los cuentos.

Sin embargo, se desconoce cuál fue la actitud del régimen hacia este relato. Asimismo, se ignora si esas reticencias fueron distintas en Espańa o Portugal. No podemos obviar que, en la zona lusa, prácticamente en los mismos años que se desarrolló la dictadura española, tuvo lugar el régimen de Salazar, que también optó por imponer su propio modelo de censura (Rodrigues 70-71). La comparativa se hace aún más intrigante si valoramos que respecto al discurso oficial de ambos estados, el control de las lecturas infantiles maduró de forma sospechosamente paralela y homogénea.

Esto sucede concretamente en la década de los cincuenta, pues en 1952 España crea la Junta Asesora de Prensa Infantil y Portugal hace exactamente lo mismo con la instauración de su Comissão Especial para a Literatura Infantil e Juvenil. Además, en el mismo quinquenio se aprueban las dos normativas censoras, Portugal lo hace el 15 de diciembre de 1950 con las Instruçóes sobre Literatura Infantily al otro lado de la frontera en 1955 se da a conocer el Reglamento de Publicaciones Infantiles y Juveniles. Pese a la relevancia de estos documentos, que ejercieron de guía para los autores que quisieran publicar sus obras en España o Portugal, no sabemos con exactitud cómo obraron las dos censuras con respecto al relato que nos ocupa y menos aún cuáles fueron las enmiendas que impusieron.

Los investigadores citados en esta sección detienen sus estudios en las etapas previas a las dictaduras, concretamente en 1937, fecha en la que Disney proyecta la película de este cuento. No se trata de un detenimiento de las investigaciones, más bien de un vacío de trabajos documentales que analicen qué sucedió con este relato desde los años cuarenta hasta los setenta, pues los estudios continúan e incluso se juzga su repercusión en la sociedad contemporánea superada esta fecha. El silencio puede deberse a dos motivos: uno, porque son los años de la censura gubernamental y su misión era no dar a conocer las acciones del Estado con respecto a la literatura; el segundo es que hasta hace relativamente poco el acceso a los expedientes originales de censura no ha sido posible.

\section{Objetivos, metodología y fuentes}

Ante el contexto expuesto y las preguntas planteadas por los especialistas predecesores nos interesamos por conocer cómo actuó la censura española ante el cuento de Blancanieves y si esos vetos también fueron aplicados en Portugal. En concreto, establecemos tres objetivos interdependientes: 1. Realizar una cronología de las reticencias hacia el cuento de Blancanieves durante ambas dictaduras; 2. Determinar cuáles fueron los focos temáticos 
que suscitaron las objeciones de los censores; 3. Calibrar si lo vetado mantuvo relación con lo estipulado en los reglamentos de publicaciones de literatura infantil y juvenil de 1955 . Las respuestas a estas tres cuestiones se plantean desde una mirada crítica a lo obrado en zona lusa con el mismo título, pues se trata de realidades censoras similares.

Los expedientes consultados en Portugal demuestran que hubo una aceptación plena y sin ningún tipo de condiciones a las galeradas que recibieron. Los expedientes seleccionados se aceptaron en su totalidad, hecho que no sucedió en España, donde todas las propuestas tuvieron algún tipo de incidencia. Después de trabajar los tres objetivos anteriores nos planteamos conocer si el contenido prohibido por el franquismo se autorizó al otro lado de la frontera o si, por el contrario, no hubo nada que recriminar, posiblemente porque el editor o adaptador realizó un ejercicio previo de autocensura.

Para perquirir esta situación nos amparamos en dos tipos de fuentes primarias: por un lado, en la legislación de literatura infantil y juvenil de cada país; por otro, en el cotejo de ocho expedientes originales de censura (seis españoles y dos portugueses, cuyos números de expedientes incluimos más abajo). Estos últimos pertenecen al Archivo Torre do Tombo y corresponden al texto anónimo A Branca de Neve e os Sete Anóes, para el Teatro Variedades, 1944 (3024) y la versión de Lucia Benedetti de Branca de Neve, 1967 (6123), ambos tramitados por compañías de teatro. Respecto a la dictadura hispana se han obtenido dos informes de 1953: un texto de Teresa Branys, Blancanieves (3487-53) y una traducción de los hermanos Grimm, Blancanieves y los siete enanitos (7311-53). Cuatro ediciones de los años setenta: Blancanieves de Jesús Flores Lázaro (4977-71), una versión anónima (10343-73), una edición para colorear (13340-74) y otra atribuida a los hermanos Grimm (6437-75). De cada uno daremos debida cuenta en las páginas sucesivas, indicando el veredicto del censor, la temática de la incidencia y el contenido vetado en cada evaluación.

\section{Las ediciones en la década de los cincuenta}

Forges, que vivió la censura en primera persona y ha sido reconocido con el Premio a la Libertad de Expresión, indicaba que "el fascismo tiene miedos insospechados" y que gracias a la envergadura de las "estupideces del Régimen" nunca faltó inspiración a los viñetistas de la prensa (Tena, R. 2018a 120). Precisamente de eso nos vamos a ocupar en estas páginas, de mostrar las fobias más insospechadas de los censores en el cuento de Blancanieves, junto con la transcripción de sus argumentos para imponer las supresiones. El primer expediente español data del 11 de junio de 1953 y su evaluación estuvo a cargo de la censora Isabel Niño, que resaltaba como aspecto positivo del relato que la inocencia sale vencedora y es castigada la maldad. Sin embargo, aclara que esa maldad está representada en la envidia de la madrastra con el consabido inconveniente de ser esta la persona de autoridad a quien se debe respetar.

Estudios previos como el que nos ofrece Gómez (141) manifiestan que desde las instituciones se trabajó por determinar un prototipo de identidad femenina del que era muy difícil desligarse. Su finalidad era clara: había que educar a las niñas para que, además de futuras mujeres sumisas y dependientes, fueran una madre y esposa ejemplar que obrara bajo los mandatos del catolicismo. Esa misma beatería era la que indicaba que no podía haber una progenitora que renegase de sus hijos. Si tenemos en cuenta que la censora de 
este expediente era la misma que dirigió el Gabinete de Lecturas de Santa Teresa de Jesús, es evidente que sabía tanto del discurso político como del religioso (Cerrillo, P. y Sanz, A. 2016). En cualquier caso, aunque manifiesta que la redacción no le agrada, la acepta porque reconoce que por ser un cuento fantástico pasa desapercibido para la mayoría de los niños (expediente 3487-53).

No obstante, tan solo seis meses después la editorial Símbolo tramita el expediente número 7311-53 y, aunque el argumento es prácticamente idéntico, la administración condiciona su autorización a una imposición. La censora María África Ibarra deduce que la narración se ha modificado haciéndola menos infantil al tratar los amores de Blancanieves y el Principe azul. No obstante, esto no implica enmiendas, lo grave es que en la página 9 debe modificarse la palabra "milagrosamente" por otra que sea más propia de cuentos de hadas. Literalmente expresa que, de ser así, se podría aceptar su edición, es decir, supedita la publicación de todo un cuento a tan solo una palabra que no le agrada.

Además, el seguimiento de este expediente desvela que no estamos ante una valoración temperamental de una persona particular, sino ante una decisión firme y meditada. Así lo demuestra la carta que emitió el Servicio de Inspección de Libros a la editorial responsable y en la que se determina taxativamente que la Dirección General de Información ha propuesto trasladarles el referido texto para que suprima lo indicado en la página 9, solo así se procederá a una segunda evaluación con la que obtener la tarjeta de autorización definitiva.

El texto original al que hemos tenido acceso demuestra que efectivamente se recrea una especie de milagro. Por tanto, no hay error de expresión por parte del traductor, ni tampoco se trata de una errata de imprenta. El desenlace del cuento recrea como el príncipe es informado del fallecimiento de su amada, por consiguiente, parte a galope hacia donde se hallaban los enanitos y al abrir la urna de Blancanieves volvió milagrosamente a la vida. Además, a diferencia de lo que sucede en otros relatos, ahora se prescinde de pócimas, encantamientos o "besos salvadores" y ocurre verdaderamente un auténtico milagro. No obstante, investigaciones previas que analizan los cuentos de hadas en el franquismo revelan que estamos ante un patrón de conducta muy arraigado. La palabra que se debía utilizar era "magia", pues el término "milagro" era de uso exclusivo para la iglesia. Concretamente, la censura temía que los niños confundieran a las hadas con vírgenes, a Dios con un mago y las acciones bíblicas con simple superchería mágica. Esto explica la protección del concepto "milagro", cuyo uso se restringió para que no se banalizara su significado y dejara de causar impacto cuando se mencionara en algunas lecturas infantiles (Tena, R. y Soto, J. 2018).

Si nos planteamos qué sucedió en Portugal, partimos de la premisa de que los dos expedientes juzgados por el salazarismo en 1944 y 1967 fueron aceptados sin enmiendas, con lo cual lo que nos preocupa es si la materia punible en Espańa se incluyó en los cuentos portugueses. Particularmente buscamos si el relato recrea el concepto de maldad en la figura de la madrastra y si hay mención a la palabra "milagro". Respecto a la primera cuestión no solo se alude a la crueldad de la figura materna, sino que además se hace intensamente y de manera continuada, desde la presentación hasta el desenlace. Así lo prueba la obra de 1944, donde la protagonista comienza explicando en primera persona que existe uma madrasta tão má, que só me deseja a morte (3), continúa sentenciando que 
esta odienta rainha (5) y concluye testificando que es uma madrasta velhaca, que me odeia e ordenou me matassem com uma faca (9). Por otra parte, la obra de 1967 acrecienta la maldad de la madrastra y extiende su malicia a los sirvientes palaciegos. Así lo reconoce el personaje:

Rainha: Há muito tempo que tenho o coração de Botabaixo [escravo] guardado numa caixa [...] agora que ele não tem coração é um óptimo escravo. Faz tudo que mando e náo sente nada. (23)

Con el veto a los milagros sucede exactamente lo mismo, Portugal no se conforma con recrear su significando o aludir a este término prohibido en Espańa, lejos de atenuar su impacto en el lector, la propia narración se reafirma en que el concepto adecuado es ese y no otro. Cuando los habitantes del bosque conocen que Blancanieves ha despertado determinan con rotundidad que milagre houve com certeza (6). De la misma manera en el cuento de 1967, también se incluye esa palabra, pero con el agravante de que ahora se vincula aún más con la magia, justo lo que el franquismo recriminaba. El relato describe que existe un "filtro milagroso" (76) que ayudará a que los personajes localicen el corazón malvado de la reina y lo conviertan mágicamente en bondadoso. La relación con la iglesia en este entramado es inexistente y a pesar de ello los censores portugueses no reseńan esta cuestión.

\section{Inicio de los años setenta (1971-1973)}

España se adentra en esta nueva década de la pre-muerte de Franco con importantes cambios en el control de la literatura infantil y juvenil. Los dos expedientes anteriores databan de 1953, pero para esa fecha aún no existía una legislación específica que regulase cómo debería ser su evaluación. Sin embargo, en 1955 se publicó el reglamento con los temas prohibidos para la infancia, en 1962 se crea la Comisión de Información de Publicaciones Infantiles y Juveniles (CIPIJ) y en 1967 se aprueba el Estatuto que regulará las lecturas para niños. Este documento fue de gran relevancia, pues manifiesta que la censura continuará siendo obligatoria para la literatura infantil y juvenil, mientras que las ediciones para adultos estaban exentas de ese trámite, según la Ley de Prensa e Imprenta de 1966.

Esta ambivalencia abre una discusión entre la bibliografía especializada que valora si en el tardofranquismo hubo o no apertura hacia los temas tradicionalmente vetados. Para Martín Antonio (2000 192), a partir de este momento los editores se van a encontrar un equipo técnico que ha profesionalizado su función como gestor de la ortodoxia y que, con la legislación en la mano, estrecha la exigencia del cumplimiento de las normas. Sin embargo, Carrasco (2014 13) aprecia mayor permisividad a la hora de publicar obras, un argumento que avala recordando que en estos años se importaron obras extranjeras, regresaron autores exiliados y se editaron títulos anteriormente denegados. El término medio entre estas dos teorías lo ubicamos en el estudio de Sotomayor (2007) que determina que estamos ante una evolución limitada que, aunque posibilita abordar nuevos temas, no favorece que se haga con la amplitud y el enfoque que los jóvenes demandaban. 
Si nos centramos en el cuento que nos ocupa encontramos dos expedientes españoles, uno de 1971 y otro de 1973. El primero lo firma Jesús Flores Lázaro con la editorial Vilmar y lo juzga el censor 22. No obstante, ni el marco de aparente aperturismo que promocionaba el Estado ni la tradición del texto sirvieron de antecedentes para aceptar este pequeño cuento sin objeciones. De hecho, la censora resalta que, aunque muy breve no evita esta adaptación de Blancanieves presentar a la madre adoptiva como ser perverso y malvado. Por consiguiente, sigue sancionando exactamente lo mismo que veinte años atrás, con la diferencia de que ahora se ha agudizado la actitud sancionadora. El expediente no 3487 de 1953, aunque reseñaba algo similar, concluía que al ser un cuento fantástico el componente negativo pasaba desapercibido para los niños y se aceptaba sin enmiendas.

En esta nueva evaluación el ministerio informa a la editorial de que para eludir dicha imagen destructiva ante el niño y los tintes de truculencia del relato, se recomienda suprimir lo marcado en páginas 1, 5 y 8. La búsqueda de esas páginas en la versión original ratifica que tenían en común la alusión a las palabras "envidia" y "maldad", como rasgos representativos de la madrasta. Una situación que da veracidad a la conclusión de la investigación de Vasquez (2003), que determinaba que en los años setenta la censura regresó para imponerse más fuertemente. Así lo corrobora Cristina Vizcaíno, cofundadora de la Editorial Fundamentos, que expone como en los años setenta estas conductas "quirúrgicas" que "extirpaban" palabras concretas fueron frecuentes. El motivo es que debido al bajo nivel cultural de los censores tenían unas consignas que aplicaban a rajatabla, con mentalidad policial (Tena, R. 2018b 387).

\begin{tabular}{|c|l|}
\hline Páginas & Texto del cuento original marcado para su supresión \\
\hline 1 & $\begin{array}{l}\text { Una vez existió una niña tan bella y de piel tan blanca que todos la } \\
\text { llamaban Blancanieves. Pero la niña no era feliz, por la envidia de su } \\
\text { madrastra, que era la reina. }\end{array}$ \\
\hline 5 & $\begin{array}{l}\text { Cuando la reina se enteró se disfrazó de anciana y dio a Blancanieves } \\
\text { una manzana envenenada. iAl morderla caería fulminada! Su envidia } \\
\text { la llevaba a tan mala acción. }\end{array}$ \\
\hline 8 & $\begin{array}{l}\text { Los sabios del país del joven príncipe le salvaron la vida y antes de } \\
\text { casarse, la madrastra quedó castigada por su maldad, reinando ellos } \\
\text { muy felices. }\end{array}$ \\
\hline
\end{tabular}

Texto instado a supresión en el cuento de Blancanieves de 1971. Fuente: expediente 4977-71

Ante esta situación cabría la hipótesis de que estamos ante un informe elaborado por un evaluador demasiado incisivo, o ante una situación muy determinada, un contexto que podría ser certero, de no ser porque dos años más tarde la Administración volvió a actuar del mismo modo. En septiembre de 1973, la editorial Susaeta cursó el expediente $n^{\circ} 10343$, en el que el funcionario nuevamente aconseja que se eliminen algunas secciones controvertidas, particularmente las recreadas en las páginas 1, 2, 3 y 17. Estos vetos se justifican alegando que el argumento no se ha cuidado lo suficiente al adaptar a menores 
(niños) los consabidos aspectos de inadecuación de este cuento (madrastra deshumanizada y propósitos de infanticidio).

El mismo contenido que a comienzos de los años cincuenta se aceptaba, sin agradar a los evaluadores, ahora es motivo de vetos. La justificación es pareja, lo que ha variado es que ahora existe una legislación que, aunque muy ambigua, es suficiente para que el censor pueda apoyar legalmente sus decisiones. Eso le otorgaba la fortaleza para actuar como tiempo atrás deseaba internamente, pero no deliberaba de forma oficial y pública. Para Lidia Falcón, escritora y líder feminista, la causa de este tipo de actuaciones a las puertas de la Transición se debe a que la mojigatería que tanto gustaba al régimen siempre estuvo vigilante $y$ desde censura cuidaban mucho que las publicaciones para niñas fueran edulcoradas y se corregian elementos muy absurdos que rozaban lo ridiculo (Tena, R. 2019a 147).

De forma concisa, la acción que no tolera el ministerio en los expedientes de 1971 y 1973 es el propósito de matar a Blancanieves. Así lo aclara el último censor, que alude directamente a que lo inapropiado es el "infanticidio". Si cotejamos este alegato con lo obrado en Portugal, apreciamos que sus dos cuentos mantienen el intento de asesinato, una concesión aperturista, máxime cuando se tramitaron en censura para ser representadas teatralmente. La primera para una fiesta de beneficencia en el Teatro Variedades y la segunda para el Teatro de Brincar, propiedad de Curado Ribeiro, con sede en el Teatro ABC ${ }^{2}$. Este hecho es importante pues, como indica la investigadora Muńoz (2006), el teatro siempre fue objeto de gran vigilancia, pues llegaba a un público más amplio, se entendía con mayor facilidad y podría incorporar mensajes ocultos en su escenificación.

La dictadura lusa permite que la madrastra verbalizase claramente la intención de matar a la protagonista en los años cuarenta, así lo exponía el personaje cuando encargó el homicidio a uno de los cazadores de palacio: Mas em breve esta fingida [Branca de Neve] vai ser entregue à morte [...] Desta ideia que tracei sois vós o encarregado. Ireis matá-la em segredo e sereis remunerado (4). Esta tolerancia se revalida en la obra de 1967, donde el relato se endurece, ya que por una parte concreta que la misión es conducir a la niña a un oscuro bosque lleno de animales feroces y una vez allí decapitarla. Por otro lado, la reina no conforme con lo truculento de este pasaje se dirige a su hijastra con el apelativo "imbécil" y aclara que su muerte debe producirse de manera agónica, poco a poco, lentamente (27). Con todos estos elementos, es evidente que las diferencias entre la tolerancia de ambos países fueron mayúsculas, tanto en el contenido como en las formas.

\section{Últimos años de dictadura (1974-1975)}

Se considera que a dos años de la muerte del dictador español la censura era un entramado reblandecido, débil y reducido a un mero trámite. Sin embargo, aunque esta idea es muy defendida, la revisión de los expedientes de censura demuestra que esto no fue así y menos aún en la literatura infantil y juvenil. De hecho, la escritora Rosa Montero comenzó su trayectoria en medios escritos durante esta etapa y asevera que entre 1973 y 1975 ya empezaron a editarse medios más arriesgados que, aunque lograban publicar, más tarde eran multados. Como ejemplo del nivel de vigilancia expone que el director general de televisión y exministro franquista Rosón llamó a la directora de una revista femenina en la que colaboraba escribiendo acerca de televisión, para exigir mi cabeza (y yo era, en serio, el último mono de allí, una colaboradora de 22 años) (Tena, R. 2019b 314). 
Si un alto cargo del franquismo se preocupaba por lo que escribía una joven veinteañera, hasta entonces desconocida, para una revista de televisión en los años de la censura de "consulta voluntaria", podemos intuir cómo se juzgaron los cuentos infantiles, cuya revisión era de "consulta obligatoria". En este contexto nos ocupamos de los expedientes 13340 y 6437. El primero fue tramitado por la editorial FHER en 1974, se trata de una edición en la que era prácticamente imposible encontrar errores, porque además de ser un relato excesivamente breve, se presentaba como un libro para colorear. Sin embargo, el censor 22 concluyó que no por ser tan breve esta adaptación del famoso cuento deja de merecer objeciones, pensando en que va dirigido a niños de corta edad. Conviene, pues, suprimir siquiera los cuatro términos marcados en rojo (hacen alusión a las archiconocidas improcedencias de este cuento).

Así, el ministerio delibera en diciembre de 1974 que solo si se acatan las indicaciones de veto podría editarse con la categoría de infantil. En honor a la verdad debemos precisar que el superior rubrica en ese mismo expediente que, según su criterio, el libro podría autorizarse por tratarse de un clásico. En todo caso, la obtención de las pruebas de imprenta ejemplifica que lo atentatorio realmente fueron las ilustraciones y particularmente las prendas que portaban las mujeres del cuento. La censura critica el volumen de los pechos de Blancanieves y el vértice de sus codos, mientras que lo objetable en la figura de la madrastra será el cinturón que agudiza la curva de sus caderas y el maquillaje ocular.

Estas evidencias documentales casan con lo investigado por Gómez (2013 145) sobre la representación femenina en los semanarios de sucesos españoles. En ellos se manifiesta que las mujeres debian ser "bonitas o graciosas" pero "no bellas o bellísimas", para que no provocasen las más bajas pasiones. Una buena mujer es "apuesta, bonita, sencilla y de cara amable” [...] porque lo que aporta belleza es un carácter abnegado y trabajador. Esta afirmación coincide con las imágenes que el censor marca y que concentran las tachaduras en los complementos.

A la problemática de la exaltación de la belleza se adhiere en 1975 el clásico inconveniente que arrastraba el cuento desde sus orígenes: la presentación de actos crueles. La mención a esta causa acredita el inmovilismo de la censura infantil a tan solo cinco meses de la muerte de Franco. La aversión particular hacia esta obra se refleja nítidamente en el informe número 6437, en primer lugar, porque requiere de la revisión de dos censores $y$, en segundo, porque el cuento pertenece a un compendio de varios clásicos y entre ellos el único censurado es este. Así lo defiende el primer lector, informando que con la modificación de los textos marcados en las páginas 3, 4, 5, 14, 15, 18, 19 y 20 y las ilustraciones de las hojas 1, 2, 6 y 7 se podría aceptar el libro completo, porque el resto de las narraciones eran autorizables.

Como se puede deducir por la generosa enumeración anterior, modificar todo lo que se expuso en la resolución implicaba rescribir el cuento por completo. De este modo, la censura se mostraba como una institución afable que no denegaba los permisos, entre otros motivos porque no le hacía falta. Normalmente, la propia editorial retiraba voluntariamente su trabajo para no editarlo carente de calidad o sin sentido argumental. En lo que concierne a este ejemplar, registrado por Bruguera, apreciamos tres factores denunciables. El primero, todo el léxico relacionado con el homicidio: "degollar", "ahorcar" y "envenenar" son prueba de ello. El segundo, la inclusión de insultos como "insolente" o 

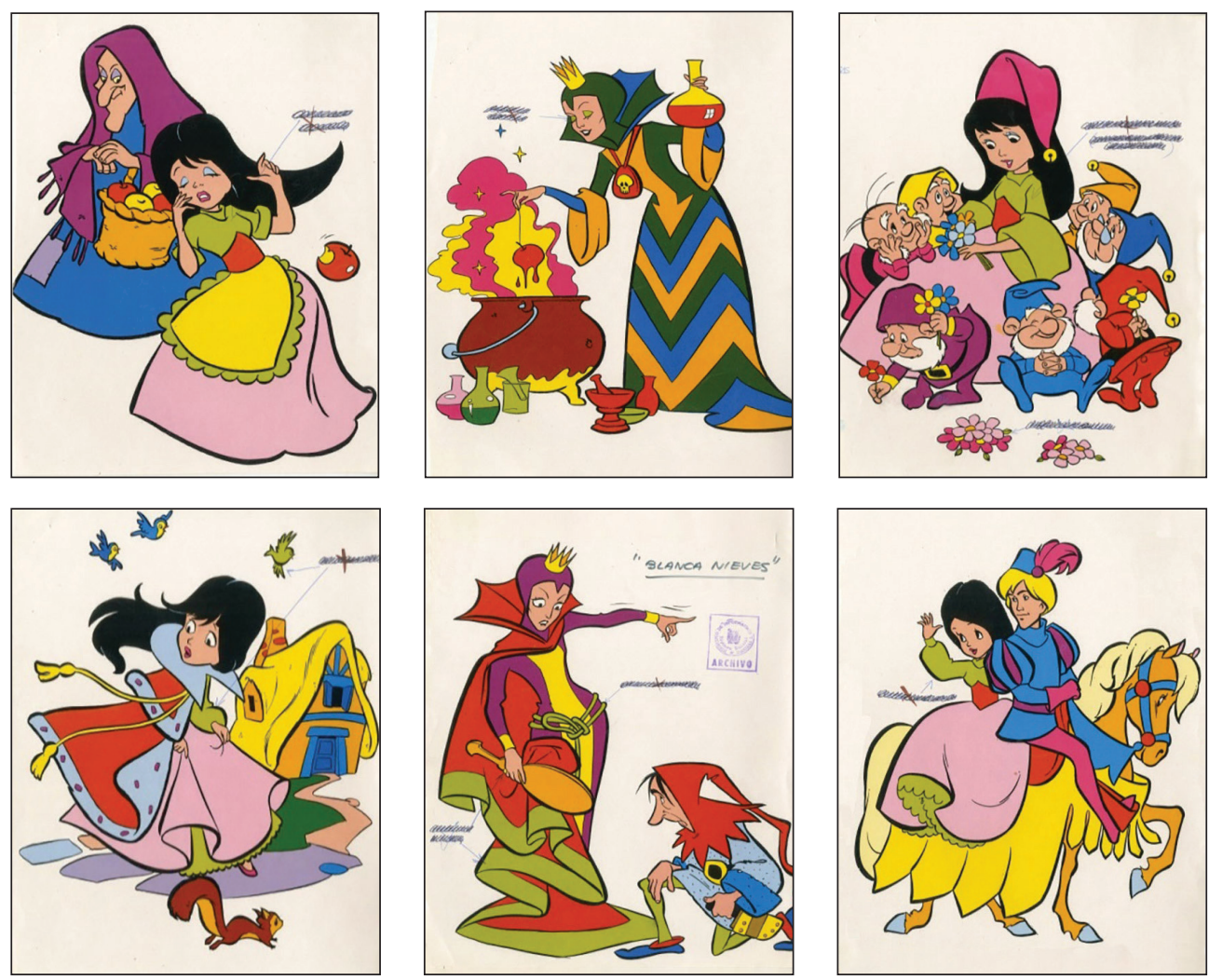

Ilustraciones tachadas en Blancanieves. Fuente: expediente 13340-74

"mal nacido" y, en tercer término, cualquier aspecto vinculado a la maldad humana. No importaba que aludiera a la madrastra (envidiosa, vengativa y colérica) o a los enanitos, seres que se mostraban "excitados y furiosos" con el fallecimiento de Blancanieves.

Los factores referenciados, aunque no estaban tachados por el censor, es lo único que podía ser punible en las páginas mencionadas. Una vez más es la superioridad institucional quien rebaja la resolución, que al día siguiente de instarse estas supresiones, determina que el cuento de "Blancanieves" en su versión original está universalmente aceptado. Se suele escenificar hasta en colegios religiosos con asistencia de superiores autoridades eclesiásticas y civiles. Opinamos que puede autorizarse. Javier Alfaya (2003 58) identificó en los falangistas un vocabulario ambivalente, "cuajado de untuosa beatería", y en los tecnócratas del Opus Dei un discurso marcado por una "pegajosa verborrea piadosa”. Un lenguaje que pretendía calar en la sociedad a través de lecturas maniqueas, edulcoradas y predecibles, que, aunque no casaban con la realidad social, su aceptación en la literatura infantil y juvenil era lo más recomendable para evitar reticencias con la censura.

Portugal, por su parte, no encuentra conflictos en la estética del personaje principal o en la revelación de escenas truculentas. Los dos expedientes de este país tampoco condicionaron su autorización al "visionado de la obra", un requisito frecuente en España, cuando el cuento que se iba a representar teatralmente podía tener incidencias eróticas 
o sanguinarias, justo lo que sucede en este relato. En las galeradas de 1944, una de las virtudes más simbólicas de Blancanieves es su belleza, así lo reconoce el príncipe cuando la ve por primera vez: Deus te salve, linda flôr de tão tocante beldade. Nunca vi rosto mais lindo, nem mais fresca mocidade (1). El personaje lo enuncia de manera continuada, pues en la página siguiente enfatiza que nunca vio un rostro semejante en toda su vida.

Sin embargo, la belleza se aborda de una forma muy generalizada en este cuento, donde realmente se acentúa el "erotismo" es en el ejemplar de los años sesenta, en él se describe a una joven que es branca como a neve, tem os cabelos negros como o ébano e os lábios vermelhos como o sangue (16). Esa misma recreación habría sido poco factible en Espańa, pues años después de aceptarse este texto en zona lusa, el franquismo se escandalizó por el maquillaje de la madrastra (así lo prueba el expediente 13340-74). Si tenemos en cuenta que no agradó esta exaltación de un ser catalogado como despreciable y asesina, más difícil sería aludir a los "labios rojos" de una protagonista, clasificada como personaje bueno, menor de edad y preocupada únicamente por mantener limpia la casa de los enanos.

No podemos obviar que la finalidad de la censura era que la infancia encontrara referentes de imitación afines a la ideología del régimen y las lectoras tenían que aprender a distinguir entre lo bello y lo erótico, para tal fin se les recordaba que la auténtica belleza estaba en su carácter servicial, no en la estética corporal. Lo primero se cultivaba trabajando duro y lo segundo era un regalo de Dios (Tena et al. 2016). Prueba de esta idea es que, pese a las reticencias de la censura española con los libros de importación traducidos al castellano, se toleraron sin ningún tipo de enmiendas títulos como Ya no eres una niña de Betty Cornell (Tena et al. 2016). El éxito administrativo radicaba en su carácter formativo, pues se presentaba como una referencia que ayudaría a la joven adolescente a pasar a la edad adulta de manera feliz.

Esta felicidad se supeditaba a encontrar un buen marido, pero al cumplimiento de ese objetivo no iban a ayudar los cosméticos o los vestidos, el éxito estaba en formarse en las labores del hogar. Así se expresa en este libro que, a modo de confesión entre amigas, reconoce a las lectoras que la mayor parte de los hombres prefieren mejor casarse con una buena cocinera que con una chica muy vistosa, pero que no sepa hacer nada. Todas debéis aprender a cocinar y saber preparar apetitosos platos y postres (1964 42). Afirmación que, aunque labrada fuera de España, casaba con el discurso oficial de Franco (1939), pues el dictador reconocía de manera pública que la finalidad de las jóvenes del país era "reconquistar los hogares españoles”, pues su heroicidad no estaba en la esfera pública, sino en el ámbito familiar y doméstico.

\section{Algunas conclusiones}

Al inicio de este trabajo concretamos tres objetivos que hemos analizado basándonos en los documentos originales y fuentes primarias, como son los informes de censura y galeradas primigenias que tramitaron las editoriales durante los regímenes de Salazar y Franco. En este sentido, el primer cometido era realizar una cronología por los veredictos deliberados en ambos países sobre el cuento de Blancanieves. El cotejo de sus expedientes ha demostrado claramente un aperturismo máximo en la sociedad lusa en comparación con lo vivido durante el franquismo. Mientras que en Portugal no se objeta absolutamente nada en los ańos cuarenta ni en los sesenta, en España todas las consultas tuvieron algún 
tipo de incidencia, sin importar la versión tramitada, la editorial, el ministro responsable o el marco temporal. La distancia es aún mayor si apreciamos que los textos portugueses estaban ideados para ser representados en teatros infantiles y, al menos en España, esta cuestión era más sangrante que la edición de un libro enfocado a la lectura individual. No era lo mismo evaluar un contenido para ser leído, que representar su argumento de forma pública.

El segundo punto que pretendíamos perquirir eran los focos temáticos que causaron controversia para la censura. Aquí solo podemos mencionar el caso español, que fue el único Estado que identificó materia punible, particularmente siempre se aquejó de cinco tipologías de ataques a la infancia. El primero relacionado con la maldad de la madrastra, pues no se vio con buenos ojos que la figura del mal personificara en un personaje con relación filial respecto a la protagonista. El segundo factor fue la mención directa al propósito de infanticidio, no era ético narrar en una lectura dirigida a los niños que existían personas que podían tener interés en su homicidio. En relación a estas cuestiones, el tercer componente que se recrimina son los actos de crueldad, sin importar quien los ejecute $\mathrm{u}$ ordene, la mera mención a conceptos relacionados con la muerte implicó tachaduras censoras.

Los dos últimos aspectos difíciles de recrear en este cuento fueron el milagro de la resurrección de Blancanieves del sueño eterno en el que estaba sumida y la exaltación de su belleza estética. En lo tocante al "milagro", la censura expresa de manera tajante que esa no es la palaba adecuada para los cuentos de hadas en los que impera la "magia", ese es el término que se debe utilizar y no el religioso. Por otra parte, existe cierto recelo a abordar la apariencia física de los personajes femeninos, con independencia de que sea un ser malévolo o de carácter angelical. No se toleran los elementos que acentúen la belleza, sobre todo si son complementos que marquen curvas o resalten rasgos faciales (maquillaje, collares o pendientes).

El último propósito de este estudio era calibrar si lo censurado mantenía relación con el Reglamento español de publicaciones de literatura infantil y juvenil de 1955. En este aspecto, podemos destacar que los cinco temas señalados como imputables tuvieron relación directa con las pautas reconocidas en esta legislación. Prueba de que fue un documento relevante y de referencia interna, es que, aunque la censura siempre recriminó el mismo contenido, a partir de su aprobación no solo delibera negativamente, también impone supresiones para las recreaciones que antes toleraba, muy a su pesar. El documento otorga a los censores el poder para vetar lo que anteriormente no se atrevían, porque no hay mayor perversión que identificar obscenidades donde las hay. De hecho, en este trabajo se ha documentado como en varias ocasiones la superioridad censora tuvo que rebajar las resoluciones de su equipo evaluador, que incluso en el mismo año de la muerte de Franco seguía represaliando lo mismo que veinte años atrás.

\section{Notas}

${ }^{1}$ Este trabajo se incluye en las actividades realizadas por el Grupo de Investigación “LIJ” del Catálogo de grupos de la Junta de Extremadura (SEJ036), Coordinado por José Soto Vázquez. Ayudas cofinanciadas por FONDOS FEDER. Programa Operativo FEDER de Extremadura 2014-2020. No de Expediente GR18026. Este trabalho é financiado por Fundos Nacionais através da FCT - Fundação para a Ciência e a Tecnologia no âmbito do projeto do CIEC (Centro de Investigação em Estudos da Criança da Universidade do Minho) com a referência UID/CED/00317/2019. 
${ }^{2}$ El Teatro Variedades y el Teatro ABC fueron partes de un recinto de espectáculos llamado Parque Mayer, en Lisboa. Era un recinto de mucha vida nocturna, en el Parque Mayer transitaban fuerzas progresistas, que burlaban hábilmente a la censura, lo que contribuyó a avalar el régimen dictatorial portugués.

\section{Bibliografía}

Alfaya, Javier. Crónica de los años perdidos: La España del tardofranquismo. Madrid: Temas de hoy, 2003.

Basile, Giambattista. Pentamerón. El cuento de los cuentos. Madrid: Siruela, 2006.

Begué Hernández, Pablo. "La feminidad de la Vieja Europa en el imaginario colectivo norteamericano: El caso de Blancanieves y los siete enanitos (1937)". VIII Congreso virtual sobre Historia de las Mujeres, coordinador por Manuel Cabrera Espinosa, 2016, pp. 65-81.

Bettelheim, Bruno. The Uses of Enchantment: The Meaning and Importance of Fairy Tales. New York: Random House, 1976.

Bono Barbero, Carmen y Guichot Reina, Virginia. "De Blancanives (1937) a Mulán (1998): análisis de los valores, normas y roles sociales transmitidos a través de las películas de Walt Disney”. La educación de las mujeres: nuevas perspectivas, coordinado por Consuelo Flecha García y Marina Núnez Gil, Universidad de Sevilla, 200145-52.

Carrasco Domingo, Estíbaliz. Censura y traducción durante el franquismo. Trabajo Fin de Grado de la Universitat Jaume I, 2014.

Cerrillo Torremocha, Pedro C. y Sanz Tejeda, Arantxa. "Lectura, Iglesia y sociedad". Revista de Estudios Socioeducativas (RESED), n. 4, 2016, pp. 27-36.

Cixous, Hélène; Clément, Cathérine. The Newly Born Woman. Minneapolis: University of Minnesota Press, 1975.

Franco, Francisco. Discurso a las militantes de la Sección Femenina de Falange. Medina del Campo: Sección Femenina, 1939.

García Padrino, Jaime. Historia crítica de la Literatura Infantil y Juvenil en la España actual (1939-2015). Madrid: Marcial Pons, 2018.

Gómez Nicolau, Emma. "El destino natural de las mujeres. La legitimación de la violencia de género a través de la prensa sensacionalista del franquismo". Nóesis: Revista de Ciencias Sociales y Humanidades, n. 22, 2013, pp. 134-159.

Grimm, Hermanos. Cuentos escogidos de los hermanos Grimm. Madrid: Gaspar y Roig, 1866.

Grimm, Hermanos. Cuentos de los hermanos Grimm para los niños. Madrid: M. M. de Santa Ana, 1885.

Grimm, Hermanos. Cuentos de los hermanos Grimm. París: Garnier Hermanos, 1886.

Grimm, Hermanos. Cuentos de los hermanos Grimm. Barcelona: Editorial Ramón Sopena, 1933.

Grimm, Hermanos. Blancanieves y los enanitos. Barcelona: Editorial Juventud, 1941.

Grimm, Hermanos. La hermosa Blancanieves. Fantasía escénica en tres actos. Llanes: Teatro Benavente, 1950.

Grimm, Hermanos. Cuentos completos de los hermanos Grimm, traducción directa del alemán por Francisco Payarols. Barcelona: Editorial Labor, 1955.

Martens, Hanna V. L. "Tradición y censura en las traducciones de literatura infantil y juvenil en la cultura franquista: Los cuentos de Perrault en español hasta 1975”. Tesis doctoral de la Universidad de Extremadura, 2016.

Martí, Alezandra. "Las princesas de los cuentos infantiles clásicos: ¿̨mujeres-objeto o mujeres-sujeto?”. La familia en la literatura infantil y juvenil: A familia na literatura infantil e juvenil, coordinado por Ana Margarida Ramos y Carmen Ferreira Boo, ANILIJ, ELOS, CIEC, 2013, pp. 227-237.

Martín Rogero, Nieves. "Cuentos de hadas bajo censura en España". Prohibido leer: La censura en la literatura infantil y juvenil contemporánea, coordinado por P. C. Cerrillo Torremocha, y César Sánchez Ortiz, Universidad de Castilla La Mancha, 2016, pp. 53-61.

Martín, Antonio. Apuntes para una Historia de los tebeos. Barcelona: Ediciones Glénat, 2000.

Martínez Sariego, Mónica María. "Lo que los adultos encontraron en los libros para niños: (sobre) interpretación de los cuentos de hadas en la crítica contemporánea”. Impossibilia, n. 8, 2014, pp. 64-85.

McGlathery, James M. Fairy Tale Romance. The Grimms, Basile, and Perrault, Urbana/ Chicago: University of Illinois Press, 1991.

Mourey, Lilyane. Introduction aux contes de Grimm et de Perrault. Paris: Lettres Modernes. Archives des Lettres Modernes, 1978. 
Muir, Percy. English Children's Books 1600-1900. 4th impression. London: Anchor Brendon Ltd. $1954 / 1985$.

Muñoz Cáliz, Berta. Expedientes de la censura teatral franquista. Fundación Universitaria Española, 2006.

Perera Santana, Á. Manual de Literatura Infantil. Las Palmas: Universidad Palmas de Gran Canaria, 2007.

Rodrigues, G. A. Breve história da censura literária em Portugal. Lisboa: Ministério da Educação e Ciência, 1980.

Ruiz Campos, A. M. Literatura infantil. Introducción a su teoría y práctica. Sevilla: Guadalmena, 2000.

Ruiz de Elvira, Antonio. Mitología clásica. Madrid: Gredos, 1975.

Sánchez Hernández, Tomás. "De los Grimm a Disney. Un estudio metodológico de la adaptación de Blancanieves". Con A de animación, n. 4, 2014, pp. 110-125.

Segura Graíno, Cristina. "Modelos desautorizados de las mujeres en los cuentos tradicionales". Arenal: Revista de historia de mujeres, 2014, n. 2, pp. 221-241.

Silva Bárbara, Maria Elisabete Da. Os contos de Perrault em Portugal no Estado Novo. Tesis doctoral de la Universidad de Coimbra, 2014.

Simonsen, Michèle. Perrault. Contes. Paris: PUF, 1992.

Sotomayor Sáez, Ma Victoria. "El humor en la literatura infantil del franquismo". Anales de Literatura Española, n. 19, 2007, pp. 237-251.

Tena Fernández, Ramón. "Antonio Fraguas, Forges: Las estupideces del Régimen eran de tal envergadura que nunca nos faltó inspiración". Revista de Occidente, n. 443, 2018a, pp. 115-123.

Tena Fernández, Ramón. "Reacciones de la editorial Fundamentos ante la censura franquista". Revista Chilena de literatura. Especial Literatura y Guerra, n. 98, 2018b, pp. 383-394.

Tena Fernández, Ramón. "Lidia Falcón y la defensa de la literatura feminista durante la censura franquista". Confluencia. Revista Hispánica de Cultura y Literatura, v. 34, n. 2, 2019a, pp. 142-153.

Tena Fernández, Ramón. "Rosa Montero: El metalenguaje es la defensa natural de la sociedad en un régimen dictatorial". Taller de letras, n. 64, 2019b, pp. 307-315

Tena Fernández, Ramón; Martens, Hanna; Soto Vázquez, José. “Dos modelos diferentes de escribir para niñas durante el franquismo". Prohibido leer: La censura en la literatura infantil y juvenil contemporánea, coordinado por P. C. Cerrillo Torremocha, y César Sánchez Ortiz, Universidad de Castilla La Mancha, 2016, pp.75-85.

Tena Fernández, Ramón; Ramos, Ana Margarida; Soto Vázquez, José. “Comparative analysis of children’s and young people's literature censorship in Spain and Portugal through laws published by Franco's and Salazar's dictatorships". Bulletin of Spanish Studies: Hispanic Studies and Research on Spain, Portugal and Latin America, 2019, en imprenta.

Vásquez Vargas, M. "La actual narrativa infantil y juvenil española". Revista de filología y lingüistica de la Universidad de Costa Rica, n. 29, 2003, pp. 61-84.

Zapata Ruiz, Teresa. El cuento de hadas, el cuento maravilloso o el cuento de encantamiento. Cuenca: Ediciones de la Universidad de Castilla-La Mancha, 2007.

\section{Legislación}

Direcção dos Serviços de Censura. Instruçōes sobre Literatura Infantil. Empresa Nacional de Publicidade, 1950

Jefatura del Estado. "Ley 14/1966, de Prensa e Imprenta". BOE, n. 67, 1966, pp. 3310-3315.

Ministerio de Información y Turismo. "Decreto 195/1967, de 19 de enero, por el que se aprueba el Estatuto de Publicaciones Infantiles y Juveniles". BOE, n. 37, 1967, pp. 1964-1967.

Ministerio de Información y Turismo. "Orden acordada en Consejo de Ministros de 24 de junio de 1955 por la que se desarrolla el Decreto sobre ordenación de las publicaciones infantiles y juveniles". $B O E, \mathrm{n}$. 33, 1956, pp. 841-845.

Ministerio de Información y Turismo. "Orden de 10 de noviembre de 1954 referente a la Junta Asesora de la Prensa Infantil”. BOE, n. 323, 1954, pp. 7739.

Ministerio de Información y Turismo. "Decreto de 24 de junio de 1955 por el que se establecen las normas a que han de ajustarse las publicaciones infantiles y juveniles". BOE, n. 204, 1956, pp. 4509-4510.

Presidência do Conselho. "Decreto-Lei 38964". Diário do Governo, n. 241, 1952, pp. 1053-1056. 


\section{Expedientes de censura}

Anónimo. A Branca de Neve e os Sete Anōes. Archivo de Torre do Tombo, 1944, Expediente PT/TT/SINDGE/1/3024.

Anónimo. Blancanieves (Colección cuentos para colorear). Archivo General de la Administración, 1974, FHER: Expediente 13340-74

Anónimo. Blancanieves. Archivo General de la Administración, Editorial SUSAETA, 1973, expediente $10343-73$.

Benedetti, Lucia (Adaptador: Fortunato Teixeira). Branca de Neve. Archivo de Torre do Tombo, 1967, expediente PT/TT/SIN-DGE/1/6123.

Branys Morena, Teresa. Blancanieves. Archivo General de la Administración, 1953, Editrial Símbolo, expediente 7311-53.

Cornell, Betty. Ya no eres una niña. Archivo General de la Administración, 1964, Mateu, expediente 6807/64.

Flores Lázaro, Jesús. Blancanieves. Archivo General de la Administración, 1971, Vilmar, expediente 4977-71.

Hermanos Grimm. Blancanieves y los siete enanitos. Archivo General de la Administración, 1975, Bruguera, expediente 6437-75.

Hermanos Grimm. Blancanieves y los siete enanitos. Archivo General de la Administración, 1953, Tor Figueroa, expediente 3487-53. 